\title{
UV Filters in the Aquatic Environment Induce Hormonal Effects and Affect Fertility and Reproduction in Fish
}

\author{
Karl Fent ${ }^{\star a b}$, Petra Y. Kunz ${ }^{\mathrm{ac}}$, and Elena Gomez ${ }^{\mathrm{d}}$
}

\begin{abstract}
UV-absorbing organic chemicals (UV filters) are being increasingly used in sunscreens, personal care products and in the protection of materials against UV irradiation. Environmental contamination originates from direct input from recreational activities and wastewaters. Concentrations in treated wastewaters are in the lower $\mu \mathrm{g} / \mathrm{l}$ range, whereas in rivers and lakes they are in the range of a few up to hundreds of $\mathrm{ng} / \mathrm{l}$. It is known that lipophilic UV filters accumulate in aquatic biota, but only little is known about their environmental fate. A large number of UV filters elicit hormonal effects in vitro. Estrogenic activity has also been demonstrated for some UV filters in fish in vivo. Benzophenone-1 (BP1), benzophenone-2 (BP2), 3-benzylidene camphor (3BC) and ethyl-4-aminobenzoate (Et-PABA) lead to induction of vitellogenin. 3BC and BP2 cause feminization in secondary sex characteristics of male fish, alteration of gonads in male and female fish and decrease in fertility and reproduction. The lowest observed effect concentrations for 3BC and BP2 were $3 \mu \mathrm{g} / \mathrm{l}$ and $1.2 \mathrm{mg} / \mathrm{l}$, respectively. UV filter mixtures show mainly a synergistic activity in vitro, whether this is also reflected by the in vivo activity is under investigation. In conclusion, a hazard and risk for aquatic ecosystems cannot be ruled out for the UV filter $3 \mathrm{BC}$, where histological and reproductive effects occurred in fish at low concentrations. However for BP1, BP2 and Et-PABA an environmental risk is rather low based on current knowledge.
\end{abstract}

Keywords: Benzophenone-2 - 3-Benzylidene camphor - Effects on reproduction - Estrogenicity . Hormonal effects $\cdot$ UV filters

\section{Introduction}

Compounds designed for absorption of UV light (UV filters) are important in the protection of human skin and materials from deleterious effects of UV radiation. In Switzerland and the EU UV filters, of which about 30 compounds are licensed

\footnotetext{
${ }^{*}$ Correspondence: Prof. Dr. K. Fent ${ }^{a}$

Tel.: + 41614674571

Fax: + 41614674290

E-mail: karl.fent@fhnw.ch

aUniversity of Applied Sciences, School for Life

Sciences

Gründenstrasse 40

$\mathrm{CH}-4132$ Muttenz

bSwiss Federal Institute of Technology (ETHZ)

Department of Environmental Sciences

$\mathrm{CH}-8092$ Zürich

'University of California

School of Veterinary Medicine

Department of Anatomy, Physiology and Cell Biology

Aquatic Toxicology Program

Davis, CA 95616, USA

dUMR Hydrosciences Montpellier

Université de Montpellier 1

Faculté de Pharmacie

15 Av. Charles Flahault, BP 14491

F-34093 Montpellier France
}

in cosmetics, skin and hair care products (sunscreens, shampoos, creams, fragrances etc.), find increasing use. Currently, $27 \mathrm{UV}$ filters are listed in Annex VII of the Cosmetics Directive, and in addition a further 43 chemicals are listed as UV filters in an inventory of ingredients used in cosmetic products by the EU. ${ }^{[1]}$ In the USA, where sunscreens are categorized as over-thecounter drugs, $16 \mathrm{UV}$ filters are permitted by the FDA. In sunscreens the concentration of a specific UV filter varies between $0.5-10 \%$, but may even reach $25 \% .{ }^{[2]}$ Mainly two groups of compounds are applied, often in combination; UV-absorbing organic chemicals, and inorganic light scattering and $\mathrm{UV}$ light reflecting $\mathrm{ZnO}$ and $\mathrm{TiO}_{2}$ particles, the latter mainly as nanoparticles. In addition, many more organic chemicals are used for absorption and stabilization of UV light to protect materials such as textiles, household products, fabrics, optical products, agricultural chemicals and many others by application of $0.05-2 \%$ on or into the product. The amount of UV filters added to personal care products and materials is increasing, because higher sunlight protection factors are in demand, and thus generally higher percentages of different UV filters are applied.

It is therefore not surprising that UV filters enter the aquatic environment either directly via wash-off from skin and clothes during recreational activities, or indirectly via sewage or swimming pool waters. Even landfill leachates ${ }^{[3]}$ or release from coatings from building parts ${ }^{[4]}$ may be sources. The environmental behavior and fate in aquatic systems is largely unknown, apart from basic information on the behavior in sewage treatment plants (STP). UV filters are photostable and many of them relatively stable in the aquatic environment against abiotic and biotic degradation. Their lipophilicity as represented by their $\log \mathrm{K}_{\mathrm{ow}}$ values varies from 0.89 for benzophenone-4 (BP4) to 5.14 for 4-methylbenzylidene camphor (4MBC), 6.1 for 2-ethyl-hexyl4-trimethoxycinnamate (EHMC), 6.88 for octocrylene (OC), up to 8.1 for octyltriazone (OTC) ${ }^{[4]}$.

Due to direct inputs, high levels of five UV filters (including benzophenone-3 (BP3), EHMC, 4MBC) ranging up to 40 $\mu \mathrm{g} / \mathrm{l}$ have been detected in swimming pool waters. ${ }^{[5]}$ Another important source is 
wastewater. In Switzerland, raw wastewater contained UV filters up to $19 \mu \mathrm{g} / \mathrm{l}$ EHMC. ${ }^{[6]}$ In southern California, levels of EHMC and BP3 were in the range of 0.11 to $10.4 \mu \mathrm{g} / \mathrm{l}$. 2-Hydroxy-4-methoxybenzophenone and $\mathrm{BP} 3$ were present at $1.6 \mu \mathrm{g} / \mathrm{l}$ in raw wastewater in France. In Swiss STPs, elimination rates of lipophilic UV filters BP3, 4MBC, OC, EHMC and OTC varied between 44 and 99\%.[4,6] In treated wastewater, $4 \mathrm{MBC}$ was most frequently found (up to $2.7 \mu \mathrm{g} / \mathrm{l}$ ), followed by BP3, EHMC and OC. ${ }^{[6]}$ The levels are considerably lower in treated than raw wastewater, indicating both sorption into sewage sludge ${ }^{[4]}$ and aerobic biodegradation. Concentrations in treated wastewater were $0.06-2.7$ $\mu \mathrm{g} / \mathrm{l}$ for $4 \mathrm{MBC}, 0.01-0.7$ for BP3, $0.01-0.1$ for EHMC and 0.01-0.27 for OC. ${ }^{[6]}$

The more lipophilic UV filters $4 \mathrm{MBC}$ and EHMC are found to concentrate in sewage sludge. ${ }^{[4]}$ Average concentrations in digested sewage sludge in Switzerland range from 0.01 to $0.39 \mathrm{mg} / \mathrm{kg}$ (dry weight, d.m.) for EHMC and 0.15 to $4.98 \mathrm{mg} / \mathrm{kg}$ (d.m.) for $4 \mathrm{MBC}$, respectively. ${ }^{[4]}$ These UV filters accumulate also in sediment, and in particular in biota. ${ }^{[6,8,9]} \mathrm{BP} 3$ was detected in wastewater from New York City and in marine sediment in concentrations of 0.4-0.9 $\mu \mathrm{g} / \mathrm{kg}$ sediment.[10] Sediments in Slovenia contained several benzophenone-type UV filters, of which concentrations of 4-hydroxybenzophenone (4HB) were highest (average $18 \mu \mathrm{g} / \mathrm{kg}$ ). ${ }^{[11]}$

Only a few UV filters such as EHMC, OC, 4MBC, BP3, HMS, Et-PABA and BMDBM originating both from direct inputs from sunscreens and cosmetics, but also from wastewaters have been analysed so far in surface water such as lakes, rivers and coastal areas. In the upper layer of a bathing lake in Switzerland, BP3, 4MBC and OC occurred at concentrations of 80-125, 60-80 and 22-27 ng/l, respectively, ${ }^{[9]}$ but were lower in other Swiss lakes. ${ }^{[6]}$ In Slovenia, UV filters were present in rivers and lakes up to $345 \mathrm{ng} / \mathrm{l}$ (homosalate), but the most frequently found UV filter was BP3. [11] Highest levels of UV filters have been detected in coastal areas at beaches contaminated due to recreational activities. ${ }^{[12]}$ Seven benzophenone-type UV filters were found in water and soil in Korea. 4HB was found in lakes up to $85 \mathrm{ng} / \mathrm{l}$ whereas 2,4-dihydroxybenzophenone (DHB) was found in rivers up to $47 \mathrm{ng} / \mathrm{l} .[13]$ The overall levels in water from an industrial drainage were $27-204 \mathrm{ng} / \mathrm{l}$, and $18-500 \mathrm{ng} / \mathrm{kg}$ in soil samples.[13] Surprisingly, UV filters have also been detected in considerable amounts in raw and treated drinking water in southern California. Besides benzophenone, most notably, EHMC was found in the range of 0.26 to $5.61 \mu \mathrm{g} / \mathrm{l}$ in raw drinking water. ${ }^{[14]}$

Residues of 4MBC, EHMC, BP3, and HMS were also found in muscle tissue of fish from a German lake being between 21-3100 ng/g lipid (sum of all UV filters were $2 \mu \mathrm{g} / \mathrm{g}$ in perch and $0.5 \mu \mathrm{g} / \mathrm{g}$ in roach), and between 25-166 ng/g lipids weight (l.w.) in ten white fish from Swiss lakes. $[6,8]$ Whereas four UV filters were detected in fish from Swiss lakes, only two have been found in rivers receiving inputs from

wastewater. $4 \mathrm{MBC}$ occurred in the range of $0.05-1.8 \mathrm{mg} / \mathrm{kg}$ (1.w.), ${ }^{[7]}$ whereas fish from lakes had lower values of $<0.02-0.17 \mathrm{mg} /$ $\mathrm{kg}$ (l.w.) ${ }^{[6]}$ (Table 1). This indicates that UV filters originating from wastewater give rise to higher levels in fish than direct inputs from sunscreens. Moreover, OC occurred in river fish in the range of 0.04 to $2.4 \mathrm{mg} / \mathrm{kg}$

Table 1. Concentrations of UV filters in the environment and biota

\begin{tabular}{|c|c|c|c|c|}
\hline Environmental sample & UV filter & $\begin{array}{l}\text { Max. Conc. } \\
{[\mathrm{ng} / \mathrm{l}, \mathrm{mg} / \mathrm{kg} \text { dw] }}\end{array}$ & Location & Reference \\
\hline \multirow[t]{10}{*}{ Lake water } & $4 \mathrm{MBC}$ & 80 & Switzerland & {$[9]$} \\
\hline & BP3 & 125 & & \\
\hline & EHMC & 19 & & \\
\hline & $\mathrm{OC}$ & 27 & & \\
\hline & BM-DBM & 24 & & \\
\hline & BP3 & 85 & Slovenia & [11] \\
\hline & EHMC & 92 & & \\
\hline & Et-PABA & 34 & & \\
\hline & OC & 31 & & \\
\hline & $4 \mathrm{HB}$ & 85 & Korea & [13] \\
\hline \multirow[t]{5}{*}{ River water } & HMS & 345 & Slovenia & [11] \\
\hline & BP3 & 114 & & \\
\hline & EHMC & 88 & & \\
\hline & OC & 34 & & \\
\hline & $\mathrm{DHB}$ & 47 & Korea & {$[13]$} \\
\hline \multirow[t]{4}{*}{ Seawater (beach) } & $4 \mathrm{MBC}$ & 488 & Norway & [12] \\
\hline & BP3 & 269 & & \\
\hline & EHMC & 238 & & \\
\hline & OC & 4461 & & \\
\hline Raw drinking water & EHMC & 5610 & California & [14] \\
\hline \multirow[t]{6}{*}{ Raw wastewater } & $4 \mathrm{MBC}$ & 6500 & Switzerland & {$[6]$} \\
\hline & BP3 & 7800 & & \\
\hline & EHMC & 19000 & & \\
\hline & $\mathrm{OC}$ & 12000 & & \\
\hline & BP3 & 6240 & California & [14] \\
\hline & EHMC & 400 & & \\
\hline \multirow[t]{4}{*}{ Treated wastewater } & $4 \mathrm{MBC}$ & 2700 & Switzerland & {$[6]$} \\
\hline & BP3 & 700 & & \\
\hline & EHMC & 100 & & \\
\hline & OC & 270 & & \\
\hline \multirow[t]{2}{*}{ Swimming pool water } & $4 \mathrm{MBC}$ & 330 & Slovenia & [11] \\
\hline & BP3 & 400 & & \\
\hline \multirow[t]{8}{*}{ Fish (lakes) } & $4 \mathrm{MBC}$ & 3.80 mg/kg (lw) & Germany & [8] \\
\hline & HMS & 3.10 mg/kg (lw) & & \\
\hline & EHMC & $0.31 \mathrm{mg} / \mathrm{kg}(\mathrm{lw})$ & & \\
\hline & BP3 & 0.30 mg/kg (lw) & & \\
\hline & $4 \mathrm{MBC}$ & $0.17 \mathrm{mg} / \mathrm{kg}(\mathrm{lw})$ & Switzerland & [6] \\
\hline & BP3 & 0.12 mg/kg (lw) & & \\
\hline & EHMC & 0.07 mg/kg (lw) & & \\
\hline & OC & $0.02 \mathrm{mg} / \mathrm{kg}(\mathrm{lw})$ & & \\
\hline \multirow[t]{2}{*}{ Fish (rivers) } & $4 \mathrm{MBC}$ & $0.42 \mathrm{mg} / \mathrm{kg}(\mathrm{lw})^{\mathrm{a}}$ & Switzerland & [7] \\
\hline & OC & $0.63 \mathrm{mg} / \mathrm{kg}(\mathrm{lw})^{\mathrm{a}}$ & & \\
\hline \multirow[t]{4}{*}{ Sewage sludge } & 4MBC & $1.78 \mathrm{mg} / \mathrm{kg}(\mathrm{dm})^{\mathrm{a}}$ & Switzerland & [4] \\
\hline & EHMC & $0.11 \mathrm{mg} / \mathrm{kg}(\mathrm{dm})^{\mathrm{a}}$ & & \\
\hline & OC & $4.84 \mathrm{mg} / \mathrm{kg}(\mathrm{dm})^{\mathrm{a}}$ & & \\
\hline & OTC & $5.51 \mathrm{mg} / \mathrm{kg}(\mathrm{dm})^{\mathrm{a}}$ & & \\
\hline
\end{tabular}

amean concentrations; dw, dry weight; Iw, lipids weight; dm, dry matter 
(1.w.). ${ }^{[7]}$ Average levels of $4 \mathrm{MBC}$ and $\mathrm{OC}$ were 0.42 and $0.63 \mathrm{mg} / \mathrm{kg}$ (l.w.), respectively (Table 1).

These data clearly indicate that lipophilic UV filters accumulate in biota. Experimental evidence also comes from our studies, where we found that the moderately lipophilic BP2 $\left(\log \mathrm{P}_{\text {ow }}=3.16\right)$ becomes bioaccumulated during 15 days of experimental exposure to $0.01-3.1 \mu \mathrm{g} / \mathrm{g}$ body weight. This gives an average estimated bioconcentration factor (BCF) of 1.9.[15] This is much lower than the bioaccumulation that was found with experimental exposure of fish to $3 \mathrm{BC}$, where a BCF of 313 was found. ${ }^{[16]} \mathrm{UV}$ filters also accumulate in human milk.[17]

\section{Endocrine-disrupting Properties of UV Filters}

Prior to this NRP50 project, UV filters had only marginally been studied for their endocrine-disrupting activity. Consequently, our work aimed to investigate potential hormonal effects of UV filters on aquatic vertebrates in vitro and in vivo.

\section{Investigation 1: Hormonal Activity of UV Filters in vitro}

Some UV filters were previously analysed for their endocrine-disrupting potential and were found to possess estrogenic activities in vitro in cell lines and recombinant yeast. ${ }^{[18-23]}$ Homosalate, octyl-dimethyl-PABA and 4MBC have been demonstrated to elicit estrogenic activity in reporter cell lines expressing human estrogen receptors (ER). They have been shown to activate $\mathrm{ER} \alpha$ to a moderate extent and had almost no effect on ER $\beta .{ }^{[23]}$ In our studies we have shown that nine of 18 analysed UV filters and one metabolite exhibit estrogenic activity by activation of $\mathrm{ER} \alpha$ (Fig. 1). Moreover, a high proportion of commonly used UV filters has been found to exhibit multiple hormonal activities in vitro including estrogenicity, antiestrogenicity, androgenicity and antiandrogenicity through interactions with hER $\alpha$ and/or human androgen receptor (hAR). ${ }^{[25]}$ Estrogenicity of the same compounds was also observed in a recombinant yeast system expressing the rainbow trout estrogen receptor alpha $(\mathrm{rtER} \alpha)$, although the sensitivities and efficacies varied to a certain extent (Fig. 1).[24]

A surprisingly high number of $14 \mathrm{UV}$ filters inhibited the activity of E2 in the $\mathrm{hER} \alpha$ assay (Table 2), thus indicating antiestrogenic activity. Six UV filters possessed androgenic activity in the hAR assay, and a high number exhibited antiandrogenic activity (Table 2). Surprisingly, eleven com-

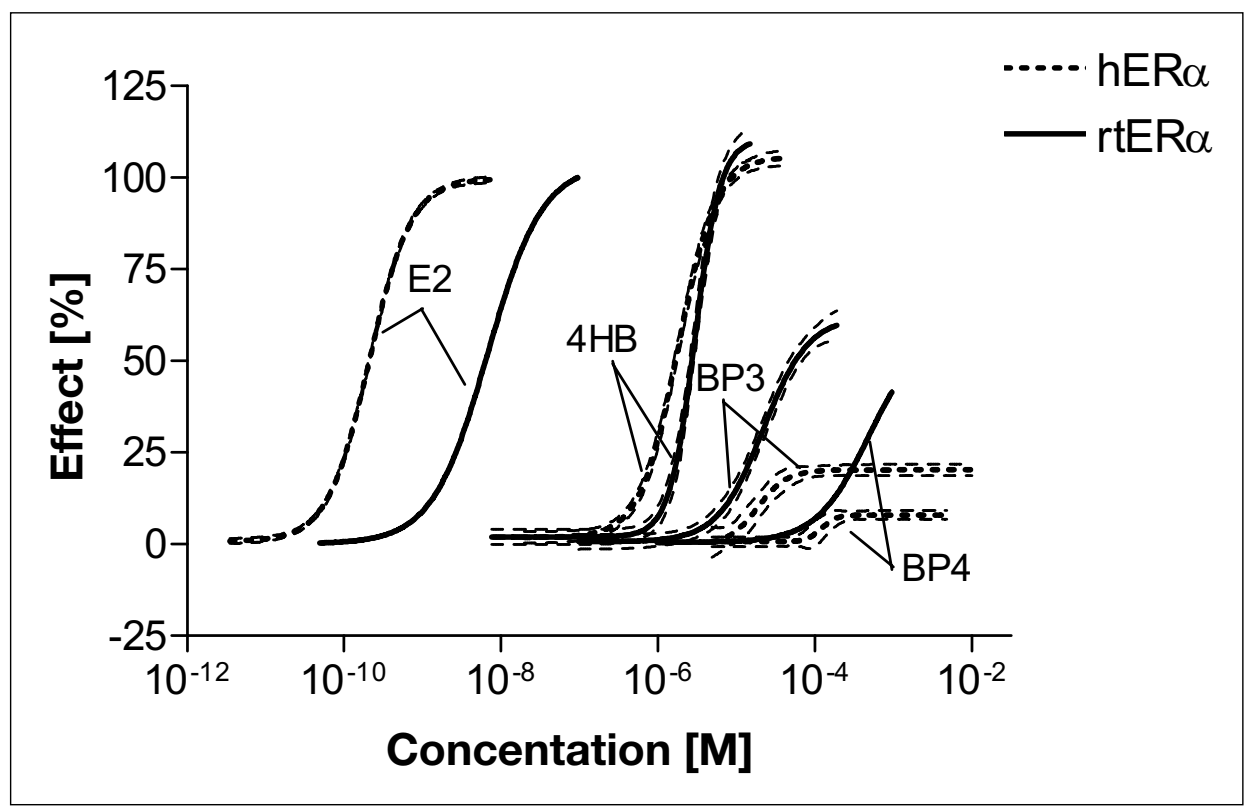

Fig. 1. Estrogenic activity of UV filters in the human $\mathrm{hER} \alpha$ and rainbow trout $\mathrm{rtER} \alpha$ recombinant yeast assay. E2, Estradiol; 4HB, 4-hydroxy benzophenone; BP3, benzophenone-3; BP4, benzophenone-4.[24]

Table 2. Hormonal activities of UV filters in vitro in the recombinant $h E R \alpha$ and $h A R$ assay[25]

\section{Compound}

4-Methylbenzylidene camphor (4MBC)

3-Benzylidene camphor (3BC)

Benzophenone-1 (BP1)

Benzophenone-2 (BP2)

4-Hydroxy benzophenone (4HB)

4,4'-Dihydroxybenzophenone (4DHB)

Benzophenone-3 (BP3)

Benzophenone-4 (BP4)

Isopentyl-4-methoxycinnamate (IMC)

Ethyl hexyl methoxycinnamate (EHMC)

Octocrylene $(\mathrm{OC})$

Benzyl salicylate (BS)

Phenyl salicylate (PS)

Homosalate (HMS)

Octyl salicylate (OS)

Para amino-benzoic acid (PABA)

Ethyl-4 amino benzoate (Et-PABA)

Octyl dimethyl para amino benzoate (OD-PABA)

Ethoxylated ethyl 4-amino benzoate (Peg25-PABA)

+++ , maximal dose-response curves with $\geq 80 \%$ efficacy; ++, submaximal dose-response curves with $\geq 30 \%$ efficacy; + , submaximal dose-response curves with $<30 \%$ efficacy. Bold, most potent hormonal activity found for each compound; --, not detected. 
pounds displayed as much as three distinct hormonal activities each. The antiestrogenic, antiandrogenic and androgenic activities of UV filters in vitro are of significant scientific and practical interest. For most of the UV filters with multiple hormonal activities residues in the aquatic environment and in biota are not yet known, however, and therefore their environmental relevance remains elusive.

\section{Investigation 2: Hormonal Activity of UV Filters in vivo and Effects on Fertility and Reproduction in Fish}

\section{Frog Metamorphosis}

We studied the potential effects of UV filters on metamorphosis of tadpoles of frogs Xenopus laevis, because metamorphosis in amphibians is a critical period for endocrine disruption. We investigated whether $4 \mathrm{MBC}$ and $3 \mathrm{BC}$ interfere with the thyroid and sex hormone system during metamorphosis. Neither 4MBC nor 3BC at concentrations of 1,5 and $50 \mu \mathrm{g} / \mathrm{l}$ affected the rate of metamorphosis, and no obvious differences were observed in body length and tail length compared to controls. ${ }^{[26]}$ At these concentrations, UV filters did not affect the sex ratio of $X$. laevis tadpoles. Obviously, neither $4 \mathrm{MBC}$ nor 3BC negatively affect the thyroid system and sex development of frogs at environmentally relevant concentrations. At high concentrations, 4MBC showed weak binding to the ER in cytosolic protein preparations from Xenopus hepatocytes, but it did not replace E2 from the ER at $0.1 \mathrm{mM} .^{[27]}$

\section{Estrogenic Activity in Fish}

The fact that aquatic organisms of sewage-contaminated environments may be exposed during their entire life cycle to UV filters with hormonal activity is of environmental concern. Estrogenicity of some UV filters has been demonstrated at high concentrations in rainbow trout ${ }^{[28]}$ and medaka. ${ }^{[29]}$ In order to investigate whether our in vitro results on estrogenicity translates to in vivo activity we exposed juvenile fathead minnows for 14 days to nine different UV filters and determined vitellogenin (VTG) induction. ${ }^{[24]}$ Seven of these UV filters were previously found to be estrogenic in vitro (BP1, BP2, BP3, BP4, DHB, ethyl-4-aminobenzoate (Et-PABA) and 3BC). In juvenile fathead minnows $3 \mathrm{BC}, \mathrm{BP} 1$ and $\mathrm{BP} 2$ led to VTG induction, ${ }^{[24]}$ and this was also found for $3 \mathrm{BC}$ in rainbow trout after injection of 68 $\mathrm{mg} / \mathrm{kg},{ }_{, 28]}{ }^{[2]}$ and aqueous exposure to $100 \mathrm{mg} / \mathrm{l}$ $4 \mathrm{MBC}$ and $10 \mathrm{mg} / \mathrm{l} \mathrm{EHMC}$ in male medaka. ${ }^{[29]}$ Among UV filters, 3BC showed the highest estrogenic potency in vivo in fish ${ }^{[24]}$ showing a dose-dependent VTG induction from $435 \mu \mathrm{g} / \mathrm{l}$ onwards (Fig. 2). Estrogenicity and significant VTG inductions were con-

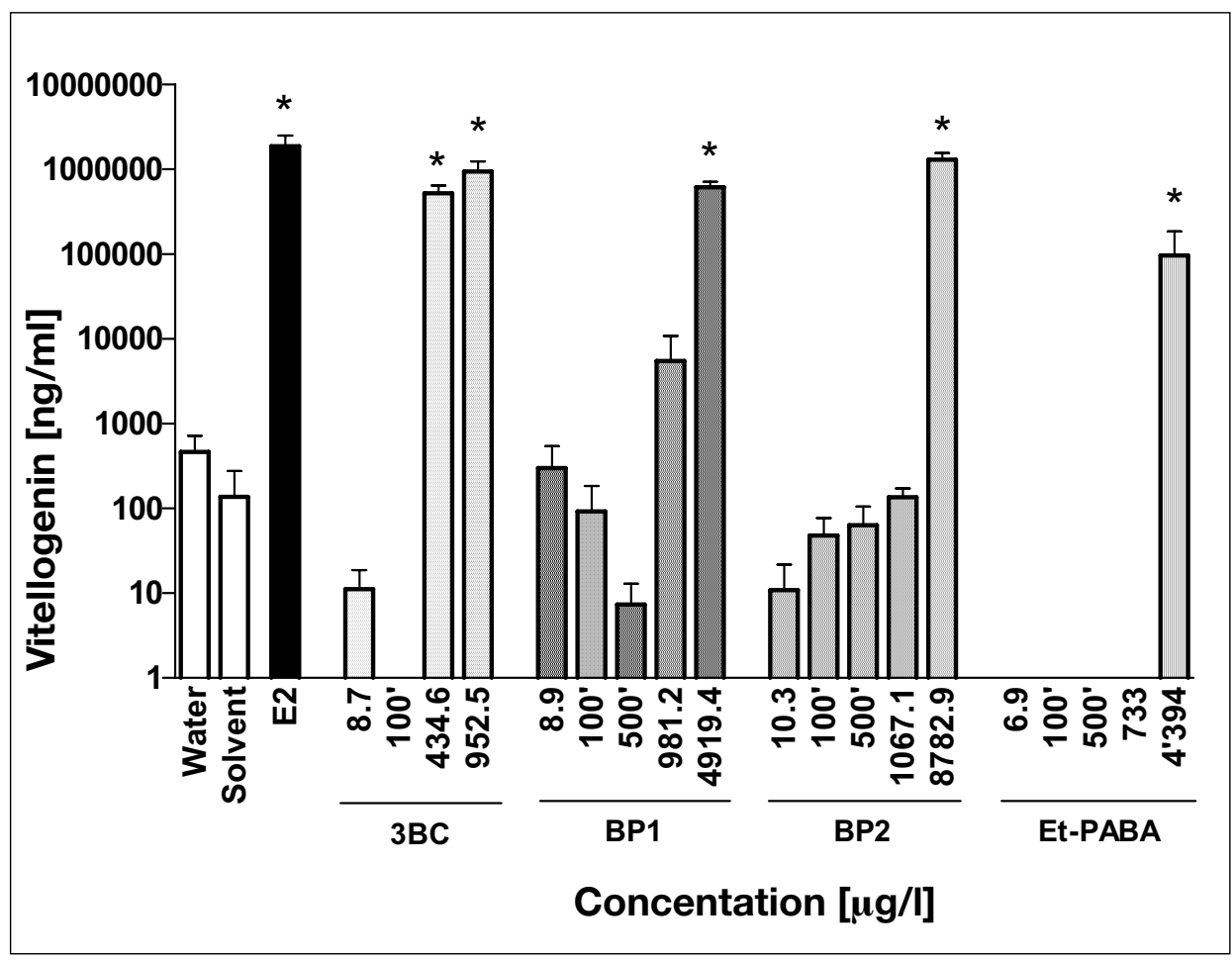

Fig. 2. Estrogenic activity of UV filters after exposure of juvenile fathead minnows for 14 days. As a biomarker for estrogenic activity, vitellogenin in fish was determined. Benzophenone-1 (BP1), benzophenone-2 (BP2), 3-benzylidene camphor (3BC) showed estrogenic activity. ${ }^{[29]}$

siderably weaker for Et-PABA $(4,394 \mu \mathrm{g} / \mathrm{l})$, $\mathrm{BP} 1(4,919 \mu \mathrm{g} / \mathrm{l})$ and BP2 $(8,783 \mu \mathrm{g} / \mathrm{l})$. The other UV filters (4MBC, EHMC, BP3, BP4, 4DHB) did not induce VTG up to the highest concentrations.

\section{Effects on Fertility and Reproduction in Fish: 3-Benzylidene Camphor}

We investigated the most potent UV filter detected in the short-term experiment with juvenile fathead minnows, 3BC, for possible adverse effects on fertility and reproduction of this fish. The estrogenicity of $3 \mathrm{BC}$ was manifested not only in a dosedependent VTG induction and reduction of male secondary sex characteristics, but also in the reduction of spawning activity caused by gonadal degeneration. Significant VTG induction in male fathead minnows was observed at $74 \mu \mathrm{g} / 13 \mathrm{BC}$ and higher. ${ }^{[16]}$ In males a significant and dose-related decrease in the number of tubercles was a clear indication for the estrogenic activity of 3BC (Fig. 3a). Males at the highest exposure concentration were visually not discernible from females and all but one had lost all tubercles. The number of nuptial tubercles in the male fathead minnow were shown to decrease when exposed to both the weak ER agonists 4-nonylphenol,[30] and the strong ER agonists E2 and EE2. ${ }^{[30,31]}$ The development of nuptial tubercles and the fatpad in male fathead minnows is stimulated by testosterone produced by the Leydig cells of the testes. Testosterone production is under the control of FSH and LH. Thus athropy of the nuptial tubercles may have resulted from an inhibition of LH because xenostrogens like 3BC may suppress androgen levels by altering neuroendocrine feedback loops. ${ }^{[32,33]}$ The number of tubercles and the production of sperm are androgen-dependent processes; they are negatively correlated with exposure to estrogenic chemicals. ${ }^{[30,34]}$ Thus, de-masculinisation reflected by these endpoints is an indication of the estrogenic activity. 3BC also significantly affected reproductive output of pair-breeding fathead minnows. Females stopped reproducing immediately after the onset of exposure at a concentration of $74 \mu \mathrm{g} / \mathrm{l} 3 \mathrm{BC}$ and higher (Fig. 4a). The cumulative number of eggs spawned, and gonadal histology were found to be sensitive parameters. The lowest observed effect concentration for the most sensitive parameter, gonadal histology, was $3 \mu \mathrm{g} / \mathrm{l}$. At 74 and $285 \mu \mathrm{g} / \mathrm{l}$ oocyte and spermatocyte development was inhibited in male and female gonads. Testes of exposed males had much fewer spermatogenic cysts, and ovaries of exposed females had much fewer mature and more atretic follicles. Reduced reproduction and even its cessation caused by $3 \mathrm{BC}$ may be related to alterations in both males and females. In males we observed a dose-dependent demasculinisation, indicated by the loss of secondary sexual characteristics, VTG induction and the inhibition of spermatogenesis. This already started at 3 $\mu \mathrm{g} / \mathrm{l}$, and possibly resulted in a loss of gender specific mating behavior and in the cessation of milt production at 74 and $285 \mu \mathrm{g} / \mathrm{l}$. In fe- 


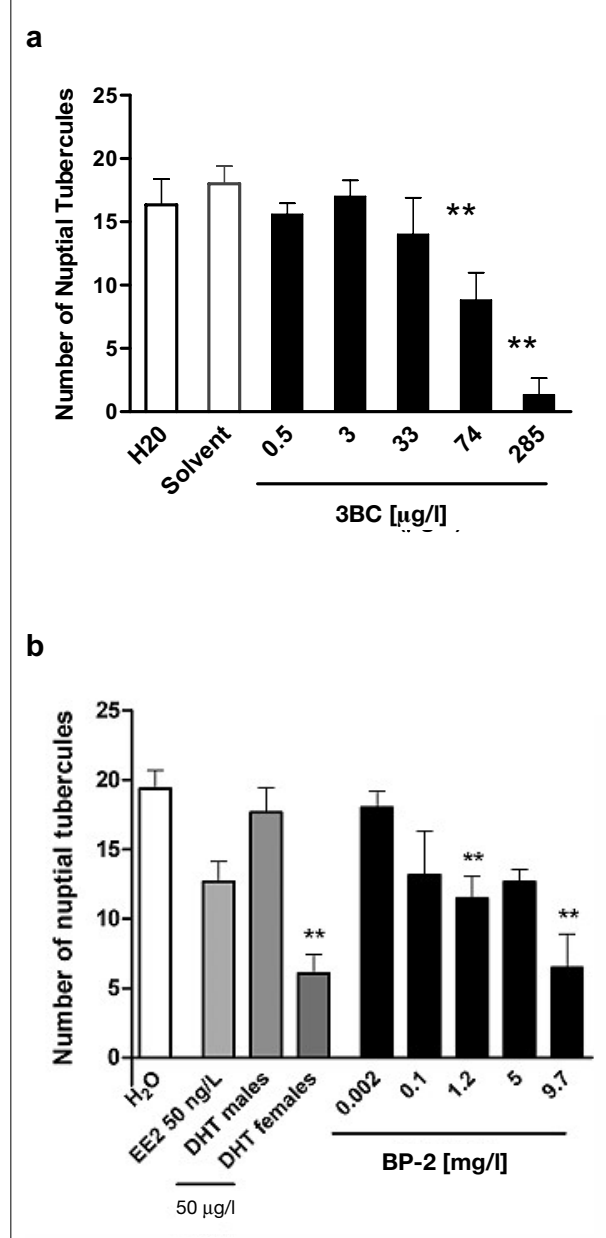

Fig. 3. Feminization of male secondary sex characteristics by 3-benzylidene camphor (3BC) (a) and benzophenone-2 (BP2) (b). Nuptial tubercles in male fish show dose-related decrease. ${ }^{[15,16]}$

males, the inhibition of oogenesis started at 3 $\mu \mathrm{g} / \mathrm{l} 3 \mathrm{BC}$ and was indicated histologically by an increase of atretic and a decrease of early and late vitellogenic follicles in ovaries. At 74 and $285 \mu \mathrm{g} / \mathrm{l}$ females stopped egg production and the release of mature oocytes. Possibly this may be a reaction on the missing mating behavior of demasculinized males present in the aquaria.

\section{Benzophenone-2}

In males, a dose-dependent VTG induction and a decrease in the number of nuptial tubercles was observed from $0.1 \mathrm{mg} / \mathrm{l} \mathrm{BP} 2$ onwards (Fig. 3b). Reduced numbers of tubercles were also observed in males exposed to EE2. ${ }^{[15]}$ Females of the androgen positive control exposed to DHT developed tubercles. However, BP2 exposed females did not develop any tubercles at all, which demonstrates the lack of androgenicity in vivo.

Reproduction was also negatively affected in a dose-dependent manner. At 1.2 $\mathrm{mg} / \mathrm{l} \mathrm{BP} 2$, fish showed reduced spawning activity (Fig. 4b). Females exposed to 5.0 $\mathrm{mg} / \mathrm{l}$ and $9.7 \mathrm{mg} / \mathrm{l} \mathrm{BP2}$ stopped spawning

a

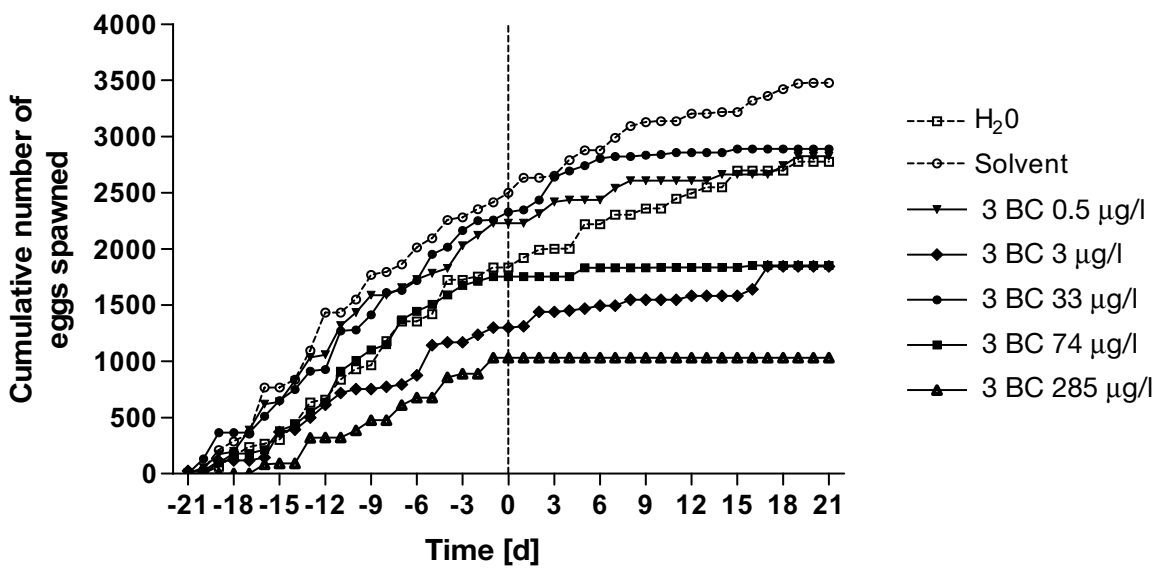

b

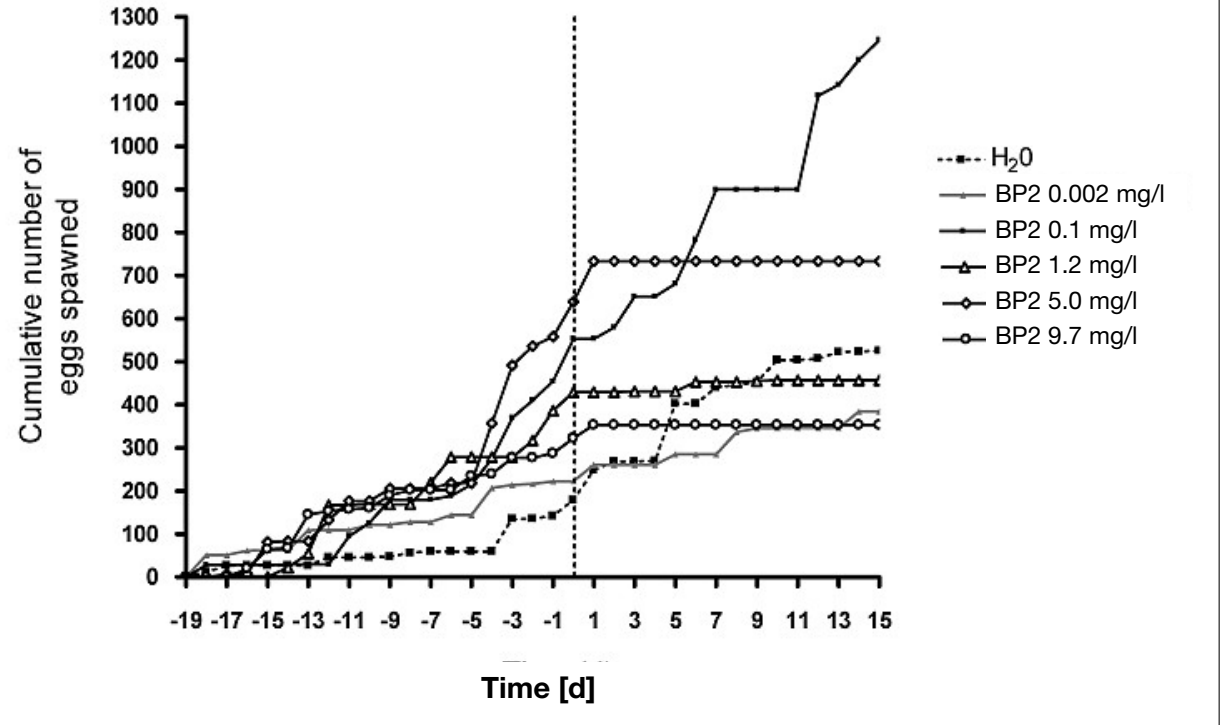

Fig. 4. Negative effects of 3-benzylidene camphor (3BC) (a) and benzophenone-2 (BP2) (b) on fish reproduction. Shown are egg numbers in the pre-exposure and exposure period. ${ }^{[15,16]}$

immediately after the onset of exposure. ${ }^{[15]}$ This effect was similar to that observed with $3 \mathrm{BC}$, although occurring at higher concentrations.

BP2 induced dose-dependent effects on gonad histology of male and female fish. Males exposed to concentrations of $1.2 \mathrm{mg} / \mathrm{l}$ BP2 and higher displayed significant alterations in the frequencies of different sperm stages present in their testes, compared to control males. This effect increased with increasing concentrations. Spermatogenesis appeared to be inhibited and testes were characterized by enlarged seminiferous tubules filled with mature sperms and the relative lack of intermediate stages (spermatocytes). Furthermore, significant dose-related effects on gonads of female fish were observed. At concentrations of 1.2 $\mathrm{mg} / \mathrm{l}$ and higher, oocyte development was significantly inhibited. Ovaries of exposed females had much fewer mature and more atretic follicles.[15] These results clearly demonstrate that BP2 significantly affected the reproduction of fish, although at higher concentrations than 3BC. The lowest observed effect concentration for gonad histology, VTG induction and secondary sex characteristics was $1.2 \mathrm{mg} / \mathrm{l}$

These findings show significant estrogenic effects of the common UV filter BP2 on vitellogenin induction, secondary sex characteristics, gonadal development, and reproduction in fish.

\section{Investigation 3: Activity of UV Filter Mixtures Showing Synergistic Activity in vitro}

The wide distribution of UV-filter mixtures in aquatic systems may have envi- 
ronmental consequences due to additive effects. The UV filters 4MBC, BP3, BP4, EHMC, OC and HMS, repeatedly detected in the aquatic environment, may contribute with their multiple hormonal activities in a complex manner to the mixture of endocrine disrupting chemicals already present in surface water and fish. As UV filters are applied as compound mixtures, it is important to understand their activity in mixture combinations. Currently, however, the interactions in UV-filter mixtures are largely unknown. A previous study using mixtures of estrogenic compounds including 2,4-dihydroxybenzophenone combined at concentrations below the no-observed-effectconcentrations (NOEC) demonstrated significant mixture effects in the yeast hER $\alpha$ assay. ${ }^{[35,36]}$ The effect of mixtures of four estrogenic UV filters on $\mathrm{pS} 2$-gene transcription was studied recently in MCF-7 cells. Mixtures of two (BP1, BP3) and four compounds (BP1, BP3, EHMC, 4MBC) showed additive activity. ${ }^{[37]}$

Mixture effects of estrogenic compounds can be calculated based on the activities of individual mixture components. The joint action of weak estrogenic compounds was recently shown to be based on the concept of concentration addition (CA) in vitro ${ }^{[35,36,38]}$ and in vivo in fish. ${ }^{[39]}$ In our study, we applied two competing pharmacological concepts for the calculation of expected additive mixture effects. ${ }^{[40]}$ The concept of CA assumes that components of a mixture act in a similar way, such that one can be replaced by an equal fraction of an equi-effective concentration of another, without weakening the overall mixture effect. Synergistic or antagonistic additivity can then be determined by applying the method of isoboles. The concept of independent action (IA) on the other hand assumes that mixture effects are the result of interactions of individual mixture components with different modes of action, and mixture components that are present below zero effects are not expected to contribute to the total mixture effect.

In our work we investigated the activities of mixtures of commonly used UV filters, which were demonstrated to be pure $\mathrm{hER} \alpha$ agonists or partial hER $\alpha$ agonists in vitro. ${ }^{[24]}$ For most of the UV-filter combinations analysed in the hER $\alpha$ assay, we found synergistic interactions. ${ }^{[40]} \mathrm{We}$ analysed eight either pure or partial hER $\alpha$ agonistic UV filters in equi-effective mixtures of two, four and eight UV filters alone, or in combination with E2 at different effect levels and at no-observed-effect-concentrations (NOEC). Most binary mixtures comprising of pure hER $\alpha$ agonists showed a synergistic activity at all mixture combinations (Fig. 5). All mixtures of four or eight, pure and partial hER $\alpha$ agonists, alone or including E2, showed synergistic activity at con-

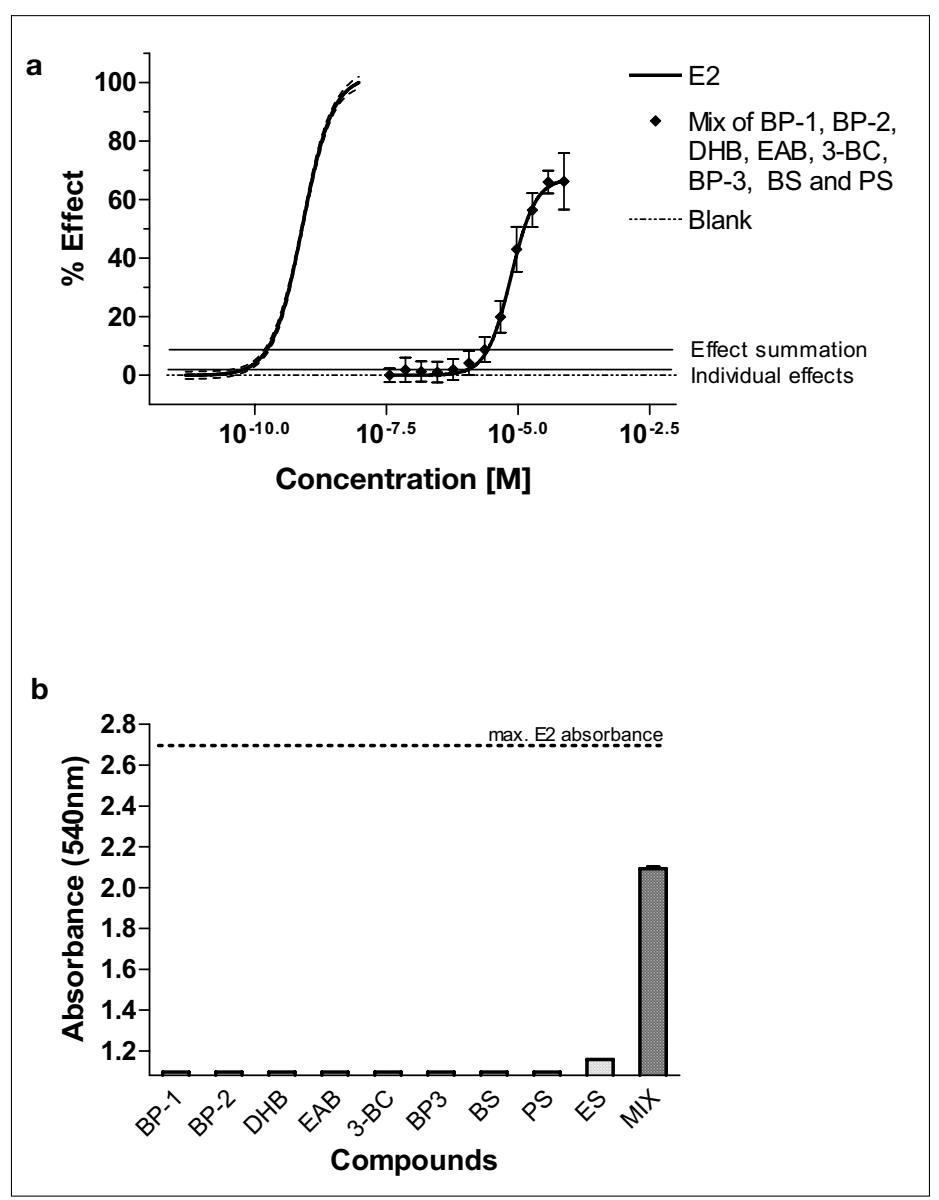

Fig. 5. Estrogenic activity of UV filter mixtures in vitro in the hER $\alpha$ assay. (a) Activity of a mixture of eight UV filters that were individually mixed at their no observed effect concentrations. (b) Effects of individual compounds and their activity as a mixture summing up the individual contribution (ES) and the measured effect (MIX) are shown. ${ }^{[40]}$

centrations giving an increase of $10 \%$ of basal activity (BC10). This occurred even at concentrations that were at the NOEC level of each single compound. Especially the pronounced synergistic effects of multicomponent mixtures of UV filters that were mixed at their NOEC indicate that low UV filter concentrations present in the environment may produce relevant estrogenic activity on their own, or lead to enhanced estrogenic activities of other more potent xenoestrogens or E2, depending on the mixture components.

Indeed, concentrations of single UV filters in the NOEC mixtures were mostly in the $\mu \mathrm{g} / \mathrm{l}$ range when eliciting highest estrogenic activities in vitro. These are effect concentrations that are close to some residual concentrations of UV filters found in the environment. Our findings on UV filter mixtures furthermore suggest that partial agonistic UV filters do not necessarily lead to a reduced overall mixture activity and antagonism. In order to evaluate whether our in vitro findings for mixtures will translate into animal cell-lines and to effects in vivo in fish, further studies are needed. Currently, we are investigating the effect of UV filter mixtures in vivo in fish.

\section{Tentative Hazard and Risk Assessment}

In the environment only a few UV filters such as EHMC, OC, 4MBC, BP3, BP4 and 4-tert-butyl-4'-methoxydibenzoylmethane (BM-DBM) have been detected so far. EtPABA, 3BC, BP1 and BP2, which were found in our studies to be estrogenic, ${ }^{[24,25]}$ have not been determined or detected so far. However, concentrations of the determined UV filters were up to $125 \mathrm{ng} / \mathrm{l}$ in lake water, up to $2.7 \mu \mathrm{g} / \mathrm{l}$ in treated wastewater, and up to $3.1 \mu \mathrm{g} / \mathrm{g}$ in fish, and thus considerably lower than the UV filter concentrations to induce VTG.

The lowest observed effect concentrations of 3BC varied according to the endpoint. For VTG induction and secondary sex characteristics it was $74 \mu \mathrm{g} / \mathrm{l}$, for effects on fecundity $33 \mu \mathrm{g} / \mathrm{l}$, and histological alterations occurred already at $3 \mu \mathrm{g} / \mathrm{l}$. VTG induction is clearly associated with other direct markers of reproduction effects and thus well suited for screening estrogenic compounds. ${ }^{[41]}$ However, for hazard and risk assessments, short-term reproduction assays provide more important toxicological and ecological information. They give 
a more detailed picture of the endocrine activities of a compound and give sensitive information on fecundity, histology and secondary sex characteristics, and thereby facilitate and refine risk assessment.

Our studies in fish showed that the lowest observed effect concentrations for $3 \mathrm{BC}$ and BP2 were $3 \mu \mathrm{g} / \mathrm{l}$ and $1.2 \mathrm{mg} / \mathrm{l}$, respectively. Other UV filters have not or only marginally been investigated. Based on current knowledge, an ecotoxicological risk assessment for aquatic organisms is premature. More data are still needed on the occurrence of UV filters in the environment and on their effects on aquatic organisms in particular after long-term exposure. Furthermore, the bioaccumulation potential and mixture activity in fish should be investigated. However, in order to evaluate whether a further risk assessment is needed, we calculated ratios of predicted or measured environmental concentrations (PEC, MEC) and predicted no effect concentrations (PNEC) based on data of currently known environmental concentrations, and results of our studies in fish.

Knowledge about environmental concentrations of UV filters 3BC, BP1, BP2 and Et-PABA demonstrated to be estrogenic in fish, is currently lacking. Therefore we assume that environmental concentrations of structurally similar compounds such as $4 \mathrm{MBC}$ and BP3 are appropriate as an approximation for the predicted exposure concentration (PEC). For clarity, we use two approaches for comparing measured (MEC) or predicted environmental concentrations (PEC) with PNEC (predicted no effect concentration, PNEC). First, concentrations in surface waters (MEC or PEC) were compared with water concentrations in experimental waters in toxicity experiments (Table 3). Second, residues in fish (based on lipid weight) from rivers were compared to body burdens of fish experimentally exposed in our studies to either $3 \mathrm{BC}$ or BP2 for determination of PNEC values (Table 4). When lipid-based weights in fish were used instead of concentrations in water, we divided the concentrations found in fish by a factor of 20 , based on the assumption that the lipids content in fish are approximately 5\%. The PNEC were either based on toxicity data from the literature or on effects found in our studies (hormonal activity, histology and reproduction effects) taking safety factors into account.

In Table 3 we used measured concentrations of $4 \mathrm{MBC}$ as a representative concentration for $3 \mathrm{BC}$, and $\mathrm{BP} 3$ as a representative for BP1, BP2 and Et-PABA, for all of which environmental concentrations are lacking. To estimate the PNEC based on experimental water (Table 3), we used the median value of the most significant reproduction parameter, which was the alteration of the gonadal histology for $3 \mathrm{BC}$ and $\mathrm{BP} 2$, and
Table 3. PEC values in surface water and PNEC values based on water concentrations in our experiments on hormonal activity of 3BC and BP2 (LOEC)

\begin{tabular}{|c|c|c|c|c|c|c|c|c|}
\hline UV filter & $\begin{array}{l}\text { Toxicity } \\
\text { acute } \\
\text { [mg/l] }\end{array}$ & $\begin{array}{l}\text { chronic } \\
\text { [mg/l] }\end{array}$ & $\begin{array}{l}\text { LOEC } \\
\text { Our exper. } \\
{[\mu \mathrm{g} / \mathrm{l}]}\end{array}$ & $\begin{array}{l}\text { Safety } \\
\text { factor }\end{array}$ & $\begin{array}{l}\text { PNEC } \\
{[\mu \mathrm{g} / \mathrm{l}]}\end{array}$ & $\begin{array}{l}\text { PEC } \\
{[\mu \mathrm{g} / \mathrm{l}]}\end{array}$ & $\begin{array}{l}\text { PEC/ } \\
\text { PNEC }\end{array}$ & $\begin{array}{l}\text { Risk } \\
\text { Assessment }\end{array}$ \\
\hline $3 B C$ & $0.141^{a}$ & $>1$ & 3.0 & 100 & 0.03 & $0.082^{d}$ & 2.73 & YES \\
\hline BP1 & $3.882^{b}$ & $>5$ & 4'919 & 100 & 49.2 & $0.125^{\mathrm{e}}$ & 0.003 & NO \\
\hline BP2 & $3.882^{b}$ & $>10$ & 1'200 & 100 & 12.0 & $0.125^{\mathrm{e}}$ & 0.010 & NO \\
\hline Et-PABA & $62.00^{\mathrm{C}}$ & $>10$ & 4'393 & 100 & 43.9 & $0.125^{\mathrm{e}}$ & 0.003 & NO \\
\hline
\end{tabular}

a3BC, $\mathrm{LC}_{50}$ in fish $96 \mathrm{~h}$, rainbow trout, SciFinder Scholar 2006; bBP3, $\mathrm{LC}_{50}$ in fish $96 \mathrm{~h}$, rainbow trout, SciFinder Scholar 2006; 'Et-PABA, LC $_{50}$ in fish $24 \mathrm{~h}$, rainbow trout, Invest Fish Control Rep. No. 87, Fish Wildl. Serv., Bur. Sport Fish. Wildl., U.S.D.I., Washington, D.C.; 50, 1979; d ref. [9]: Highest concentration of $4 \mathrm{MBC}$ found in Swiss lakes (summer 1998, $82 \mathrm{ng} / \mathrm{l}$ in Hüttensee); ${ }^{\mathrm{e}}$ ref. [9]: Highest concentration of BP3 found in Swiss lakes (summer 1998, $125 \mathrm{ng} / \mathrm{l}$ in Hüttensee)

Table 4. PEC values based on residues in fish in rivers and PNEC values based on body burdens in fish in our experiments on hormonal activity of 3BC and BP2 (LOEC)

\begin{tabular}{|c|c|c|c|c|c|c|c|c|}
\hline UV filter & $\begin{array}{l}\text { Toxicity } \\
\text { acute } \\
\text { [mg/l] }\end{array}$ & $\begin{array}{l}\text { chronic } \\
\text { [mg/l] }\end{array}$ & $\begin{array}{l}\text { LOEC } \\
\text { Our exper. } \\
\text { [ng/g] }\end{array}$ & $\begin{array}{l}\text { Safety } \\
\text { factor }\end{array}$ & $\begin{array}{l}\text { PNEC } \\
\text { [ng/g] }\end{array}$ & $\begin{array}{l}\text { PEC } \\
\text { [ng/g] }\end{array}$ & $\begin{array}{l}\text { PEC/ } \\
\text { PNEC }\end{array}$ & $\begin{array}{l}\text { Risk } \\
\text { Assessment }\end{array}$ \\
\hline $3 B C$ & $0.141^{a}$ & $>1$ & 360 & 100 & 3.6 & $90^{d}$ & 25 & YES \\
\hline BP1 & $3.882^{b}$ & $>5$ & 2000 & 100 & 20.0 & $5.9^{e}$ & 0.295 & $\mathrm{NO}$ \\
\hline BP2 & $3.882^{b}$ & $>10$ & 2000 & 100 & 20.0 & $5.9^{e}$ & 0.295 & NO \\
\hline Et-PABA & $62.00^{c}$ & $>10$ & 2000 & 100 & 20.0 & $5.9^{e}$ & 0.295 & NO \\
\hline $3 B C$ & & & & & 3.6 & $11.5^{f}$ & 3.19 & YES \\
\hline BP1 & & & & & 20.0 & $11.5^{f}$ & 0.575 & NO \\
\hline BP2 & & & & & 20.0 & $11.5^{f}$ & 0.575 & NO \\
\hline Et-PABA & & & & & 20.0 & $11.5^{f}$ & 0.575 & NO \\
\hline
\end{tabular}

a3BC, LC $_{50}$ in fish $96 \mathrm{~h}$, rainbow trout, SciFinder Scholar 2006; bBP3, LC 50 in fish $96 \mathrm{~h}$, rainbow trout, SciFinder Scholar 2006; ' $E$ Et-PABA, LC $_{50}$ in fish $24 \mathrm{~h}$, rainbow trout, Invest Fish Control Rep. No. 87, Fish Wildl. Serv., Bur. Sport Fish. Wildl., U.S.D.I., Washington, D.C.; 50, 1979; dref. [6]: lipid weight based concentration of $1800 \mathrm{ng} / \mathrm{g} 4 \mathrm{MBC}$ in brown trout from a small Swiss river, divided by 20 as an approximation for whole body concentration; ${ }^{e}$ ref. [6]: lipid weight based concentration of $118 \mathrm{ng} / \mathrm{g}$ BP3 in roach from Lake Greifen (Switzerland), divided by 20 as an approximation for whole body concentration; ${ }^{\mathrm{f} Z e n k e r} \mathrm{~A}$. (pers. communication): Highest concentration of UV filter EHMC in fish from river Glatt was $229 \mathrm{ng} / \mathrm{g}$ lipids, divided by 20 as an approximation for whole body concentration

VTG induction for BP1 and Et-PABA. We used a safety factor of 100 , which is used when acute $\mathrm{LC}_{50}$ values for fish, crustaceans or algae are known, or when chronic values for one of this group exist. Values for acute and chronic toxicity parameters, environmental concentrations and estimates for our tentative hazard assessment are found in Tables 3 and 4, based on either water or body residue concentrations.

The tentative risk assessments using both approaches (Tables 3 and 4) lead to the same results: Further hazard and risk assessments are necessary for the UV filters $3 \mathrm{BC}$, where histological and reproductive effects are assessed. For BP1, BP2 and Et-PABA, the risk quotient is lower than 1. However, the LOEC concentrations we used for BP1 and Et-PABA are based on VTG induction, which may be up two orders of magnitude less sensitive than histology towards endocrine dis- ruption, which we clearly demonstrated for 3BC. In case of BP2, VTG induction was not less sensitive than other parameters such as histological and reproductive parameters, and also in this case, the risk quotient is lower than 1. Exposure to UV filters has, however, be regarded in the context of additional UV filters and hormonally active compounds present in aquatic systems. The importance of additive interactions has been shown in experiments with fathead minnows, ${ }^{[39]}$ but also in a recombinant yeast system in vitro, where synergistic interactions of UV filters were found. ${ }^{[40]}$ Considering the interactions of a number of estrogenic compounds present in wastewater-contaminated aquatic ecosystems, BP2 may contribute to potential effects on fish reproduction, as estrogenic chemicals have the capacity to act together in an additive manner. ${ }^{[36,39]}$ Therefore, it should be considered that UV filters occur 
as mixtures that may interact in an additive fashion. Hence, a potential risk of these UV filters cannot be ruled out.

\section{Acknowledgment}

We thank the steering committee of the NRP50, in particular Christof Studer, Felix Althaus, Susan Jobling, Ana Soto and Konrad Hungerbühler for the continuous interest and support, and Hansruedi Schmutz, Hector Galicia, Christian Weisbrod and Armin Zenker for valuable collaboration.

Received: March 22, 2008

[1] S. Wahie, J. J. Lloyd, P. M. Farr, Clin. Exp. Dermatol. 2007, 32, 359.

[2] U. Hauri, B. Lütolf, C. Hohl, Mitt. Lebensm. Hyg. 2003, 94, 80.

[3] D. L. Giokas, V. A. Sakkas, T. A. Albanis, J. Chromat. A 2004, 1026, 289.

[4] C. Plagellat, T. Kupper, R. Furrer, L. F. de Alencastro, D. Grandjean, J. Tarrradellas, Chemosphere 2006, 62, 915.

[5] C. Zwiener, S. D. Richardson, D. M. De Marini, T. Grummt, T. Glauner, F. H. Frimmel, Environ. Sci. Technol. 2007, 41 , 363.

[6] M. E. Balmer, H. R. Buser, M. D. Müller, T. Poiger, Environ. Sci. Technol. 2005, 39, 953.

[7] H. R. Buser, M. E. Balmer, P. Schmid, M Kohler, Environ. Sci. Technol. 2006, 40, 1427.

[8] M. Nagtegaal, T. A. Ternes, W. Baumann, R. Nagel, UWSF-Z. Umweltchem. Ökotoxikol. 1997, 9, 79.

[9] T. Poiger, H. R. Buser, M. Balmer, P. A. Bergqvist, M. D. Müller, Chemosphere 2004, 55, 951 .

[10] D. Schlenk, Y. Sapozhnikova, M. A. Irwin, L. Xie, W. Hwang, S. Reddy, B. J. Brownawell, J. Armstrong, M. Kelly, D. E. Montagne, E. P. Koloziej, D. Sedlak, S. Snyder, Environ. Toxicol. Chem. 2005, 24, 2820.
[11] P. Cuderman, E. Health, Anal. Bioanal. Chem. 2007, 387, 1343.

[12] K. Langford, K.V. Thomas, 'Inputs of chemicals from recreational activities to the Norwegian coastal zone', in SETAC Europe 17th Annual Meeting, 2007, Porto, Portugal.

[13] H. K. Jeon, Y. Chung, J. C. Ryu, J. Chromat. A 2006, 113, 192.

[14] G. A. Loraine, M. E. Pettigrove, Environ Sci. Technol. 2006, 40, 687.

[15] C. J. Weisbrod, P. Y. Kunz, A. K. Zenker, K. Fent, Toxicol. Appl. Pharmacol. 2007, 225, 255.

[16] P. Y. Kunz, T. Gries, K. Fent, Toxicol. Sci 2006, 93, 311 .

[17] T. A. Ternes, J. Hany, W. Baumann, R. Nagel, Fresenius J. Anal. Chem. 1995 $351,790$.

[18] E. J. Routledge, J. P. Sumpter, J. Biol. Chem. 1997, 272, 3280.

[19] T. W. Schultz, J. R. Seward, G. D. Sinks, Environ. Toxicol. Chem. 2000, 19, 301.

[20] M. Schlumpf, B. Cotton, M. Conscience, V. Haller, B. Steinmann, W. Lichtensteiger, Environ. Health Persp. 2001, 109, 239.

[21] R. Schreurs, P. Lanser, W. Seinen, B. Van der Burg, Arch. Toxicol. 2002, 76, 257.

[22] S. O. Mueller, M. Kling, P. A. Firzani, A. Mecky, E. Duranti, J. Shields-Botella, R. Delansorne, T. Borschard, P. J. Kramer, Toxicol. Let. 2003, 142, 89.

[23] E. Gomez, A. Pillon, H. Fenet, D. Rosain, M. J. Duchesne, J. C. Nicolas, P. Balaguer, C. Casellas, Toxicol. Environ. Health A 2005, 27, 239 .

[24] P. Y. Kunz, H. Galicia, K. Fent, Toxicol Sci. 2006, 90, 349.

[25] P. Y. Kunz, K. Fent, Aquat. Toxicol. 2006, 79, 305.

[26] P. Y. Kunz, H. F. Galicia, K. Fent, Mar Environ. Res. 2004, 58, 431.

[27] A. Klann, G. Levy, I. Lutz, C. Müller, W. Kloas, J. P. Hildebrandt, Environ. Res. 2005, 97, 274.

[28] H. Holbech, U. Norum, B. Korsgaard, P. Bjerregaard, Pharmacol. Toxicol. 2002 91, 204.
[29] M. Inui, T. Adachi, S. Takenaka, H. Inui, M. Nakazawa, M. Ueda, H. Watanabe, C. Mori, T. Iguchi, K. Miyatake, Toxicology 2003, 194, 43

[30] S. R. Miles-Reichardson, V. J. Kramer, S. D. Fitzgerald, J. A. Render, B. Yamini, S. J. Barbee, J. P. Giesy, Aquat. Toxicol. 1999, 47, 129

[31] S. Pawlowski, R. van Aerle, C. R. Tyler, T. Braunbeck, Ecotoxicol. Environ. Saf. 2004, 57, 330 .

[32] G. T. Ankley, J. E. Tietge, D. L. Defoe, K. M. Jensen, G. W. Holcombe, E. J. Durhan, S. A. Diamond, Environ. Toxicol. Chem. 1998, 17, 2530.

[33] C. R. Tyler, B. Van der Eerden, S. Jobling, G. Panter, J. P. Sumpter, J. Comp. Physiol. B 1996, 166, 418 .

[34] K. M. Jensen, J. J. Korte, M. D. Kahl, M. S. Pasha, G. T. Ankley, Comp. Biochem. Physiol. C 2001, 128, 127.

[35] N. Rajapakse, E. Silva, A. Kortenkamp, Environ. Health Persp. 2002, 110, 917.

[36] E. Silva, N. Rajapakse, A. Kortenkamp, Environ. Sci. Technol. 2002, 36, 1751.

[37] M. Heneweer, M. Musse, J. Van der Berg, T. Sanderson, Toxicol. Appl. Pharmacol. 2005, 208, 170.

[38] J. Payne, N. Rajapakse, M. Wilkins, A Kortenkamp, Environ. Health Persp. 2000, 108, 983.

[39] J. V. Brian, C. A. Harris, M. Scholze, T. Backhaus, P. Booy, M. Lamoree, G Pojyna, N. Jonkers, T. Runnalls, A. Bonfà, A. Marcomini, J. P. Sumpter, Environ. Health Perspect. 2005, 113, 721.

[40] P. Y. Kunz, K. Fent, Toxicol. Appl. Pharmacol. 2006, 217, 86.

[41] J. P. Sumpter, A. C. Johnson, Environ. Sci. Technol. 2005, 39, 4321. 